\title{
High prevalence of respiratory symptoms among workers in the development section of a manually operated coal mine in a developing country: A cross sectional study
}

\author{
Simon HD Mamuya*1,2,3, Magne Bråtveit ${ }^{2}$, Yohana Mashalla ${ }^{4}$ and
}

\author{
Bente E Moen ${ }^{2}$
}

\begin{abstract}
Address: ${ }^{1}$ Centre for International Health, University of Bergen, Norway, ${ }^{2}$ Section for Occupational Medicine, University of Bergen, Norway, ${ }^{3}$ Department of Community Health, Muhimbili University College of Health Sciences, Dar es Salaam, Tanzania and ${ }^{4}$ Department of Physiology, Muhimbili University College of Health Sciences, Dar es Salaam, Tanzania
\end{abstract}

Email: Simon HD Mamuya* - mamuyasimon@yahoo.com; Magne Bråtveit - magne.bratveit@isf.uib.no;

Yohana Mashalla - yjmashalla@muchs.ac.tz; Bente E Moen - bente.moen@isf.uib.no

* Corresponding author

Published: I February 2007

BMC Public Health 2007, 7:17 doi:10.1186/147|-2458-7-17
Received: 7 June 2006

Accepted: I February 2007

This article is available from: http://www.biomedcentral.com/I47/-2458/7/17

(c) 2007 Mamuya et al; licensee BioMed Central Ltd.

This is an Open Access article distributed under the terms of the Creative Commons Attribution License (http://creativecommons.org/licenses/by/2.0), which permits unrestricted use, distribution, and reproduction in any medium, provided the original work is properly cited.

\begin{abstract}
Background: Few studies of miners have been carried out in African countries; most are from South Africa, where the working conditions are assumed to be better than in the rest of Africa. Several studies have focused on respiratory disorders among miners, but development workers responsible for creating underground road ways have not been studied explicitly. This is the first study assessing the associations between exposure to dust and quartz and respiratory symptoms among coal mine workers in a manually operated coal mine in Tanzania, focusing on development workers, as they have the highest exposure to coal dust.

Methods: A cross-sectional study was carried out among 250 production workers from a coal mine. Interviews were performed using modified standardized questionnaires to elicit information on occupational history, demographics, smoking habits and acute and chronic respiratory symptoms. The relationships between current dust exposure as well as cumulative respirable dust and quartz and symptoms were studied by group comparisons as well as logistic regression.

Results: Workers from the development group had the highest dust exposure, with arithmetic mean of $10.3 \mathrm{mg} / \mathrm{m}^{3}$ for current respirable dust and $1.268 \mathrm{mg} / \mathrm{m}^{3}$ for quartz. Analogous exposure results for mine workers were $0.66 \mathrm{mg} / \mathrm{m}^{3}$ and $0.03 \mathrm{mg} / \mathrm{m}^{3}$, respectively; and for other development workers were $0.88 \mathrm{mg} / \mathrm{m}^{3}$ and $0.10 \mathrm{mg} / \mathrm{m}^{3}$, respectively.

The workers from the development section had significantly higher prevalence of the acute symptoms of dry cough $(45.7 \%)$, breathlessness $(34.8 \%)$ and blocked nose $(23.9 \%)$. In addition, development workers had significantly more chronic symptoms of breathlessness (17.0\%) than the mine workers $(6.4 \%)$ and the other production workers $(2.4 \%)$. The highest decile of cumulative exposure to respirable dust was significantly associated with cough $(\mathrm{OR}=2.91,95 \% \mathrm{Cl}$ $1.06,7.97)$ as were cumulative exposure to quartz and cough $(\mathrm{OR}=2.87, \mathrm{Cl} I .05,7.88)$, compared with the reference consisting of the group of workers with the lowest quartile of the respective cumulative exposure.

Conclusion: The development workers in a coal mine had more acute and chronic respiratory symptoms than the mine and the other production workers. In addition, there was an association between high cumulative coal dust and respiratory symptoms.
\end{abstract}




\section{Background}

Respiratory diseases have a distinct role in the health of miners, with important implications for morbidity and mortality $[1,2]$. Respiratory symptoms may be early manifestations of acquired respiratory diseases, and examining such symptoms among miners can be helpful during health surveillance of these dust-exposed workers. Various studies from industrialized countries have documented the relationship between exposures to coal dust and increased respiratory symptoms. Both longitudinal and cross-sectional studies [3-8] have shown that symptoms of persistent cough and phlegm production, breathlessness and wheezing relate significantly with individual cumulative exposure to respirable mixed coal dust.

The British Pneumoconiosis Field Research among 30000 miners showed that coal dust contributes to the development of respiratory symptoms at an early age [9]. The US Coal Mine Health and Safety Act in 1969 set the legal respirable mixed coal dust standard for coal mines in the United States at $3 \mathrm{mg} / \mathrm{m}^{3}$, with a reduction to $2 \mathrm{mg} / \mathrm{m}^{3}$ in 1973. Despite these standards, studies in the United States showed statistically significant associations between cumulative exposure to respirable dust and respiratory symptoms for miners joining the industry after 1970 [10]. Henneberger \& Attfield [7] showed a high prevalence of dyspnoea and wheezing for coal workers joining the industry in the United States before 1970. This study suggested that respiratory symptoms might provide an early warning related to prior exposure and might be followed by impairment in lung functioning.

Previous studies have examined respiratory symptoms in subgroups of miners such as coal face, maintenance, transport, maintenance and surface $[11,12]$; coal face, backbye and surface [12]; and coal face, face return and face end [13]. However, the development workers who create mining paths for miners to extract coal have not been studied explicitly. In our previous study[14], this group of workers was highest exposed to respirable dust and quartz, indicating a high risk of respiratory symptoms and disorders. More information about these workers is considered to be important for health efforts in the mines, in order to avoid future respiratory disorders due to dust exposure. In developing countries, and specifically among workers in labor-intensive coal mines, few studies have investigated the relationships between respiratory symptoms and coal mine dust.

The purpose of this study is to assess the occurrence of acute and chronic symptoms and associations between symptoms and exposure to respirable dust and quartz among coal mine workers in this manually operated coal mine in Tanzania, with a special focus on the development workers.

\section{Methods \\ Study population}

A cross-sectional study was carried out at a coal mine in Mbeya, Tanzania in 2003 and 2004. Of the 556 workers in this mine, 220 workers were excluded. The excluded workers were managers, assistant managers and heads of section due to their high socio-economic status. In addition surface workers in carpentry, masonry, garage, foundry, welding, machine workshop and surveying were excluded due to other types of dust exposure. Office workers and temporary workers were also excluded. Thus, 336 workers were invited to participate; 318 participated (303 men and 15 women), giving a response rate of $94.6 \%$. The women were excluded before the statistical analysis due to their low number, as well as two workers with bronchial asthma and two with tuberculosis. The remaining 250 workers from the production part of the mine constituted the final study population. These were high-exposure workers from the development team $(n=47)$ and lowerexposure workers from the mine team $(n=78)$ and from the other production teams $(n=125)$. The tasks for the above teams are described in our previous publication (19).

\section{Questionnaire}

The coal mine workers were interviewed using a respiratory health questionnaire. The questionnaire had three parts, including personal and work characteristics, smoking habits and respiratory health symptoms. The questionnaire was prepared in English and was translated into Swahili, the national language of Tanzania, it was used in the previous study[15]. The questionnaire was pre-tested among 30 selected coal mine workers and discussed for clarity before the study started. The questions on personal and work characteristics included sex, age, education level, employment history, years worked in the mine and years in dusty work elsewhere. The questionnaire was administered between 0800 and 1600 .

Acute symptoms were assessed using a modified optimal symptom score questionnaire [16] and scored on a fivepoint Likert scale as never (1), mild (2), moderate (3), severe (4) or very severe (5). Workers were asked whether they had the following symptoms: dry cough, shortness of breath, wheezing, stuffy nose, runny nose and sneezing during or after the previous shift. Before statistical analysis, the responses were dichotomized to no (never) and yes (mild, moderate, severe or very severe).

A modified version of the British Medical Research Council questionnaire on respiratory symptoms [17] included questions on whether respondents usually had symptoms of cough, breathlessness and wheezing. The subjects were also asked whether they had bronchial asthma and/or other chronic illnesses such as tuberculosis and bronchitis 
(yes/no). Further, the workers were asked whether they had had injuries or surgery affecting the chest and whether they had had heart problems, pneumonia, pleurisy, pulmonary tuberculosis, bronchial asthma or any other chest problems in the past 3 years (yes/no). Those with any of these problems were excluded from the analysis.

Current smokers were defined as those who were smoking at the time of the study or those who had smoked more than one cigarette per day and stopped less than 1 year prior to the study. Ex-smokers were those who had smoked previously and stopped more than 1 year previously. The year they stopped smoking and the numbers of cigarettes smoked per day were also recorded. Neversmokers were defined as individuals who had never smoked.

\section{Assessment of exposure}

As part of our previous exposure assessment [14], carried out concomitantly with the presently reported questionnaire studies on respiratory symptoms, personal dust was sampled during the day shift, which normally lasted about 5-10 hours. Five full-shift samples were taken on each monitoring day. Personal respirable dust was sampled using a SKC Sidekick pump (model 224-50) with a flow rate of $2.2 \mathrm{l} / \mathrm{min}$. A rotameter was used to adjust the flow. The respirable dust samples were collected on 37$\mathrm{mm}$ cellulose acetate filters (pore size $0.8 \mu \mathrm{m}$ ) placed in a $37-\mathrm{mm}$ conductive plastic cyclone. The cassette was assembled and labeled at X-lab in Bergen, Norway. The cyclone was clipped to the worker's collar, allowing it to hang freely and collect dust in the breathing zone.

The respirable dust samples were quantified by gravimetric analysis using a Mettler AT 261 delta range with a limit of detection of $0.01 \mathrm{mg} / \mathrm{m}^{3}$. Respirable dust samples were analysed for quartz by X-ray diffraction on a silver membrane filter using NIOSH method 7500 at SGAB Analytica Laboratory, Luleå, Sweden. The limit of detection was $0.005 \mathrm{mg} / \mathrm{m}^{3}[18]$.

\section{Cumulative dust exposure}

The individual cumulative exposure to respirable dust or quartz $\left(\mathrm{mg} \cdot\right.$ year $\left./ \mathrm{m}^{3}\right)$ for the workers was estimated as the sum of the product of the estimated worker-specific mean exposure in the respective job teams and number of years the worker had spent in these job teams [19].

\section{Statistical analysis}

The Statistical Package for the Social Sciences (SPSS) version 12 was used for the data analysis. $P \leq 0.05$ was chosen as the criterion for statistical significance. The independent $t$-test was used to compare continuous variables between the development, the mine and the other production workers. The chi-square test was used to compare proportions in categorical variables. Logistic regression analysis was used for groups where the number of workers with symptoms are about 15 [20] to determine odds ratio (OR) for groups with chronic respiratory symptoms based on quartiles and the highest deciles of cumulative exposure using the lowest quartile as the reference group, while adjusting for ever-smoking and age.

Summary variables for chronic symptoms and for acute symptoms were created to evaluate the correlation between chronic and acute respiratory symptoms. For chronic respiratory symptoms this was created by summarizing the score of each symptom; to have cough first thing in the morning, cough during the day and night, cough with sputum first thing in the morning, cough with sputum during the day and night, shortness of breath when hurrying on level ground and shortness of breath walking with people of your own age on level ground. This sum score ranged from 0 to 6 . Summarizing the scores for dry cough, shortness of breath, wheezing, stuffy nose, runny nose and sneezing, created the summary variable of the acute respiratory symptoms with score $(0-5)$. Pearson correlation coefficients were calculated for estimating the correlation between acute and chronic symptoms.

\section{Ethical approval and informed consent}

Ethical approval was obtained from the Western Norway Regional Committee for Medical Research Ethics and the National Institute for Medical Research of Tanzania. The research permit was obtained from the Tanzania Commission for Science and Technology (COSTECH). There was institutional consent, since the administration of the Kiwira Coal Mine was informed of the project and allowed the study to proceed. Each person was informed about the aims of the study and the methods before being requested to consent to participate in the study voluntarily.

\section{Results}

Table 1 shows the demographic characteristics and current and cumulative exposure to respirable dust and quartz. The arithmetic mean respirable dust and quartz exposure values were 18 and 12 times higher (respectively) for the development workers than for the mine workers, and 42 and13 times higher (respectively) for the development workers than for the group of other production workers. The cumulative exposure was also considerably higher for the development workers. The prevalence of current smokers and ever-smokers was not significantly different between the three groups. The number of years in the mine was significantly higher for other production workers than for mine workers. Further, the groups did not differ significantly in age, education or height (Table 1). 
Table I: Demographic characteristics, current and cumulative exposures to respirable dust and quartz among male workers in the coal mine

\begin{tabular}{|c|c|c|c|c|c|c|c|c|c|c|c|}
\hline Exposure status & $\mathrm{N}$ & $\begin{array}{l}\text { Age } \\
(\text { years) }\end{array}$ & $\begin{array}{l}\text { Height } \\
(\mathrm{cm})^{\mathrm{a}}\end{array}$ & $\begin{array}{l}\text { Tenure } \\
(y r s)^{\mathrm{a}}\end{array}$ & $\begin{array}{l}\text { Ever } \\
\text { smokerb }\end{array}$ & $\begin{array}{l}\text { Current } \\
\text { smokerb }\end{array}$ & $\begin{array}{l}\text { Primary } \\
\text { education } \\
\text { only }\end{array}$ & $\begin{array}{l}\text { Current } \\
\text { Dusta } \\
\left(\mathrm{mg} / \mathrm{m}^{3}\right)\end{array}$ & $\begin{array}{l}\text { Current } \\
\text { Quartza } \\
\left(\mathrm{mg} / \mathrm{m}^{3}\right)\end{array}$ & $\begin{array}{l}\text { Cumulative } \\
\text { dust } \\
\text { exposurea } \\
\left(\mathrm{mg} \cdot \mathrm{yr} / \mathrm{m}^{3}\right)\end{array}$ & $\begin{array}{l}\text { Cumulative } \\
\text { quartz } \\
\text { exposure } \\
\left(\mathrm{mg} \cdot \mathrm{yr} / \mathrm{m}^{3}\right)\end{array}$ \\
\hline Development & 47 & $36.1(9.6)$ & $166.0(6.3)$ & $9.3(6.9)$ & $7(15.2)$ & $4(8.7)$ & $43(91.5)$ & $10.3(16.3)$ & $1.27(3.40)$ & $136.3(129.0)$ & 6. $7(6.3)$ \\
\hline Mine & 78 & $36.1(6.5)$ & $165.4(6.4)$ & $9.4(5.3)$ & $24(30.8)$ & $6(7.7)$ & $71(91.0)$ & $0.66(0.61)$ & $0.03(0.10)$ & $23.5(48.8)$ & $1.2(2.4)$ \\
\hline Other production workers & 125 & $36.9(6.9)$ & $163.9(6.5)$ & $11.5(5.1)$ & $30(24.0)$ & $13(10.4)$ & $108(86.4)$ & $0.88(1.6)$ & $0.10(0.46)$ & $24.5(51.4)$ & $1.5(2.6)$ \\
\hline All & 250 & $36.5(7.3)$ & 164.7(6.4) & $10.4(5.6)$ & $61(24.5)$ & $23(9.2)$ & $222(88.8)$ & $3.7(9.97)$ & $0.48(2.06)$ & $45.2(84.0)$ & $2.4(4.1)$ \\
\hline$P$ & & $0.714^{c}$ & $0.098^{c}$ & $0.008^{c}$ & $0.148^{d}$ & $0.803^{d}$ & $0.752^{d}$ & $<\left.0.000\right|^{c}$ & $<0.002^{c}$ & $<\left.0.000\right|^{c}$ & $<0.0001 \mathrm{c}$ \\
\hline
\end{tabular}

$n$ : number of workers. aArithmetic mean (standard deviation). bNumber (percentage). cAnalysis of variance. ${ }^{\mathrm{d}} \mathrm{Chi}-\mathrm{square}$.

Workers in development, mine and other production differed significantly in the acute symptoms of dry cough, breathlessness and blocked nose (Table 2). The development workers had the highest prevalence of these symptoms (Table 2). For dry cough there was a significant difference between development and mine workers ( $\mathrm{P}=$ $0.022)$ and between mine and other production workers $(P=0.047)$, respectively (Table 2$)$. For breathlessness the significant difference was between development and other production workers $(\mathrm{P}=0.005)$, while for blocked nose the significant difference was found between development and mine workers $(P=0.011)$. Among never smokers there was a significant difference between development and other production workers for breathlessness (Table 2).

For chronic symptoms the three groups of workers differed in cough as much as 4-6 times a day for 4 or more days a week and for breathlessness (Table 3). When only never-smokers were included in the analysis the three groups differed in cough with sputum production, cough as much as 4-6 times a day for 4 or more days a week and breathlessness (Table 3 ). The development workers had higher prevalence of breathlessness while walking with people of their own age than the group of other production workers $(P=0.002)$. This finding was persistent when including only the never-smokers stratification $(P=$ $0.007)$. For cough as much as $4-6$ times a day for 4 or more days a week the significant difference was between development and other production workers $(P=0.005$ for all workers and $P=0.002$ for never-smokers). There was no significant different between mine workers and the group of other production workers for any of the chronic symptoms.

The workers in the highest decile of cumulative exposure to respirable dust and quartz had significantly higher odd ratios for chronic cough compared with the reference: $2.91(1.06,7.97)$ and $2.87(1.05,7.88)$, respectively (Table 4$)$. Acute respiratory symptoms were highly correlated with the chronic respiratory symptoms $(r=0.400, P$ $<0.0001$ ).

\section{Discussion}

The workers in the development section of the mine were significantly more affected by the acute symptoms of breathlessness and blocked nose compared with the other production workers. The higher exposure to respirable dust and quartz compared with other workers might explain this [14]. Our study also associated the presence of chronic respiratory symptoms and exposure to quartz and respirable coal mine dust. The fact that the specific group of workers from the development section has higher exposure and higher occurrence of symptoms has not been shown before. It might be that, awareness of high exposure is related to greater willingness to respond

Table 2: Acute respiratory symptoms among development, mine and other production workers in the of Kiwira coal mine

\begin{tabular}{|c|c|c|c|c|c|}
\hline Symptoms & & Development workers & Mine workers & Other production workers & $P 1$ \\
\hline \multirow[t]{2}{*}{ Dry cough } & Never smoking & $17(43.69 \%)$ & $16(29.6 \%)$ & $36(37.9 \%)$ & 0.365 \\
\hline & All & 21 (45.7\%) & $20(25.6 \%)$ & 49 (39.2\%) & 0.049 \\
\hline \multirow[t]{2}{*}{ Breathlessness } & Never smoking & $12(30.8 \%)$ & $9(16.7 \%)$ & |4(|4.7\%) & 0.087 \\
\hline & All & $16(34.8 \%)$ & $13(16.7 \%)$ & $19(15.2 \%)$ & 0.012 \\
\hline \multirow[t]{2}{*}{ Blocked nose } & Never smoking & $6(15.4 \%)$ & $5(9.3 \%)$ & $15(15.8 \%)$ & 0.514 \\
\hline & All & II (23.9\%) & $6(7.7 \%)$ & 17 (13.6\%) & 0.040 \\
\hline \multirow[t]{2}{*}{ Running nose } & Never smoking & $19(48.7 \%)$ & $27(50.0 \%)$ & $53(55.8 \%)$ & 0.681 \\
\hline & All & $25(54.3 \%)$ & $37(47.4 \%)$ & $71(56.8 \%)$ & 0.425 \\
\hline \multirow[t]{2}{*}{ Sneezing } & Never smoking & $13(33.3 \%)$ & $40(42.1 \%)$ & $40(40.3 \%)$ & 0.607 \\
\hline & All & 17 (37.0\%) & $29(37.2 \%)$ & $5 I(40.8 \%)$ & 0.835 \\
\hline
\end{tabular}

'Chi-square test between the three groups of workers 
Table 3: Chronic respiratory questions asked in a study of male coal miners comparing numbers and percentage of the affected among development, mine and other production workers stratified by smoking habit

\begin{tabular}{|c|c|c|c|c|c|c|}
\hline Respiratory symptoms & & Development workers n(\%) & Mine workers n(\%) & Others production workers0 $\mathrm{n}(\%)$ & Total n(\%) & $P^{I}$ \\
\hline \multirow{2}{*}{$\begin{array}{l}\text { Do you usually cough first thing in the } \\
\text { morning? }\end{array}$} & Never smoker & $8(20.5 \%)$ & 14(25.9\%) & $20(21.1 \%)$ & $42(22.3 \%)$ & 0.754 \\
\hline & All & $10(21.3 \%)$ & $2 \mathrm{I}(26.9 \%)$ & $29(23.2 \%)$ & $60(24.0 \%)$ & 0.741 \\
\hline \multirow{2}{*}{$\begin{array}{l}\text { Do you usually cough during the day or at } \\
\text { night? }\end{array}$} & Never smoker & II(28.2\%) & $14(25.9 \%)$ & $19(20.0 \%)$ & $44(23.4 \%)$ & 0.520 \\
\hline & All & 13(27.7\%) & $21(26.9 \%)$ & $28(22.4 \%)$ & $63(25.2 \%)$ & 0.593 \\
\hline \multicolumn{7}{|c|}{$\begin{array}{l}\text { If the response was yes to any of the above, the } \\
\text { worker was asked: }\end{array}$} \\
\hline \multirow{2}{*}{$\begin{array}{l}\text { Do you usually cough as much as } 4-6 \text { times } \\
\text { a day for } 4 \text { or more days in a week? (Yes/ } \\
\text { no) }\end{array}$} & Never smoker & $8(20.5 \%)$ & $6(11.1 \%)$ & $4(4.2 \%)$ & $18(9.6 \%)$ & 0.013 \\
\hline & All & $\mathrm{II}(23.4 \%)$ & $10(12.8 \%)$ & $7(5.6 \%)$ & 14(5.6\%) & 0.004 \\
\hline \multirow{2}{*}{$\begin{array}{l}\text { Have you coughed like this on most of days } \\
\text { for as much as } 3 \text { consecutive months or } \\
\text { more in a year? (Yes/no) }\end{array}$} & Never smoker & $4(10.3 \%)$ & $2(3.7 \%)$ & $3(3.2 \%)$ & $9(4.8 \%)$ & 0.197 \\
\hline & All & $5(10.6 \%)$ & $5(6.4 \%)$ & $4(3.2 \%)$ & $14(5.6 \%)$ & 0.156 \\
\hline \multicolumn{7}{|l|}{$\begin{array}{l}\text { For cough with sputum production, a worker } \\
\text { was asked: }\end{array}$} \\
\hline \multirow{2}{*}{$\begin{array}{l}\text { Do you usually cough with sputum first } \\
\text { thing in the morning? (Yes/no) }\end{array}$} & Never smoker & $7(17.9 \%)$ & $10(18.5 \%)$ & $12(12.8 \%)$ & $29(15.5 \%)$ & 0.580 \\
\hline & All & $9(19.1 \%)$ & $15(19.2 \%)$ & $18(14.3 \%)$ & $42(16.9 \%)$ & 0.614 \\
\hline \multirow{2}{*}{$\begin{array}{l}\text { Do you usually cough with sputum during } \\
\text { the day or at night? (Yes/no) }\end{array}$} & Never smoker & $7(17.9 \%)$ & $8(14.8 \%)$ & $8(8.4 \%)$ & $23(12.2 \%)$ & 0.246 \\
\hline & All & $9(19.1 \%)$ & $12(15.4 \%)$ & $12(9.6 \%)$ & $33(13.2 \%)$ & 0.203 \\
\hline \multicolumn{7}{|l|}{ If the response was yes to any of the above: } \\
\hline \multirow{2}{*}{$\begin{array}{l}\text { Do you usually cough with sputum as much } \\
\text { as } 4-6 \text { times a day, or } 4 \text { or more days in a } \\
\text { week? (Yes/no) }\end{array}$} & Never smoker & $4(10.5 \%)$ & $3(5.6 \%)$ & $2(2.1 \%)$ & $9(4.8 \%)$ & 0.117 \\
\hline & All & $4(8.7 \%)$ & $6(7.7 \%)$ & $5(4.0 \%)$ & $15(6.0 \%)$ & 0.393 \\
\hline \multirow{2}{*}{$\begin{array}{l}\text { Have you coughed with sputum on most of } \\
\text { days for as much as } 3 \text { consecutive months } \\
\text { or more in a year? (Yes/no) }\end{array}$} & Never smoker & $3(7.7 \%)$ & $\mathrm{I}(1.9 \%)$ & 0 & $4(2.1 \%)$ & 0.019 \\
\hline & All & $3(6.4 \%)$ & $2(2.6 \%)$ & $3(2.4 \%)$ & $8(3.2 \%)$ & 0.387 \\
\hline \multicolumn{7}{|l|}{$\begin{array}{l}\text { Workers were classified as having } \\
\text { breathlessness if they answered yes to: }\end{array}$} \\
\hline \multirow{2}{*}{$\begin{array}{l}\text { Are you troubled by shortness of breath } \\
\text { when hurrying on level ground? (Yes/no) }\end{array}$} & Never smoker & $17(43.6 \%)$ & $17(31.5 \%)$ & $33(34.7 \%)$ & $67(35.6 \%)$ & 0.469 \\
\hline & All & $21(44.7 \%)$ & $25(32.1 \%)$ & $40(32.0 \%)$ & $86(34.4 \%)$ & 0.258 \\
\hline \multirow{2}{*}{$\begin{array}{l}\text { Do you get shortness of breath walking } \\
\text { with other people of your own age on level } \\
\text { ground? (Yes/no) }\end{array}$} & Never smoker & $7(17.9 \%)$ & $2(3.7 \%)$ & $3(3.2 \%)$ & $12(6.4 \%)$ & 0.004 \\
\hline & All & $8(17.0 \%)$ & $5(6.4 \%)$ & $3(2.4 \%)$ & $16(6.4 \%)$ & 0.002 \\
\hline \multicolumn{7}{|l|}{ If the response was yes to any of the above: } \\
\hline \multirow{2}{*}{$\begin{array}{l}\text { Do you have to stop for breathing when } \\
\text { walking at your own pace on level ground? } \\
\text { (Yes/no) }\end{array}$} & Never smoker & $2(5.1 \%)$ & $\mathrm{I}(1.9 \%)$ & $3(3.2)$ & $6(3.2 \%)$ & 0.675 \\
\hline & All & $3(6.4 \%)$ & $4(5.1 \%)$ & $4(3.2 \%)$ & II (4.4\%) & 0.617 \\
\hline \multirow{2}{*}{$\begin{array}{l}\text { Have you experienced wheezing sound } \\
\text { from your chest? (Yes/no) }\end{array}$} & Never smoker & $5(12.8 \%)$ & $4(7.4 \%)$ & $5(5.4 \%)$ & $14(7.5 \%)$ & 0.335 \\
\hline & All & $6(12.8 \%)$ & $6(7.7 \%)$ & $8(6.5 \%)$ & $20(8.1 \%)$ & 0.403 \\
\hline
\end{tabular}

'Chi-square test between the three groups of workers

positively to questions about symptoms. However, in our study symptoms like runny nose and sneezing, not traditionally considered to be related to dust exposure were not different between the development, mine and the others and this strengthens our findings.
Our study showed a lower prevalence of chronic symptoms than previous studies from the United States, the United Kingdom and China. This might be explained by lower dust exposure levels in the present study. Workers in the mine team (coal face) had an average exposure of 0.66 
Table 4: Logistic regression of chronic respiratory symptoms and cumulative dust and quartz in quartiles and highest decile of cumulative exposure in a study of male coal miners adjusted for age and ever smoking.

\begin{tabular}{|c|c|c|c|c|c|}
\hline Chronic symptoms & Exposure groups & Exposure $\left(\mathrm{mg} \cdot\right.$ years $\left./ \mathrm{m}^{3}\right)$ & $n$ & No (\%) & OR $(95 \% \mathrm{Cl})$ \\
\hline \multicolumn{6}{|l|}{ Cumulative respirable dust } \\
\hline \multirow[t]{5}{*}{ Cough during the day or at night } & First quartile & $0.00-3.47$ & 62 & $15(24.2)$ & \\
\hline & Second quartile & $3.48-9.27$ & 63 & $14(22.2)$ & $0.98(0.43,2.24)$ \\
\hline & Third quartile & $9.28-39.00$ & 64 & $14(21.9)$ & $0.91(0.39,2.09)$ \\
\hline & Fourth quartile & $39.01-436.75$ & 60 & $20(33.3)$ & $1.50(0.68,3.35)$ \\
\hline & Highest decile & $127.44-436.75$ & 24 & II (45.8) & $2.91(1.06,7.97)$ \\
\hline \multirow[t]{5}{*}{ Shortness of breath hurrying on level ground } & First quartile & $0.00-3.47$ & 62 & $21(33.9)$ & \\
\hline & Second quartile & $3.48-9.27$ & 63 & $15(23.8)$ & $0.62(0.28,1.34)$ \\
\hline & Third quartile & $9.28-39.00$ & 64 & $28(43.8)$ & $1.5 \mathrm{I}(0.74,3.12)$ \\
\hline & Fourth quartile & $39.01-436.75$ & 60 & $22(36.7)$ & $1.15(0.55,2.44)$ \\
\hline & Highest decile & $127.44-436.75$ & 24 & $10(40.0)$ & $1.37(0.52,3.62)$ \\
\hline \multicolumn{6}{|l|}{ Cumulative quartz } \\
\hline \multirow[t]{5}{*}{ Cough during the day or at night } & First quartile & $0.006-0.1615$ & 62 & $15(24.4)$ & \\
\hline & Second quartile & $0.162-0.432$ & 64 & $15(23.4)$ & $0.88(0.38,2.04)$ \\
\hline & Third quartile & $0.433-2.825$ & 61 & $14(22.6)$ & $0.88(0.38,2.02)$ \\
\hline & Fourth quartile & $2.826-21.372$ & 62 & $19(31.1)$ & $1.61(0.73,3.58)$ \\
\hline & Highest decile & $6.232-21.372$ & 25 & II (45.8) & $2.87(1.05,7.88)$ \\
\hline \multirow[t]{5}{*}{ Shortness of breath hurrying on level ground } & First quartile & $0.006-0.1615$ & 62 & $31(33.9)$ & \\
\hline & Second quartile & $0.162-0.432$ & 64 & $15(23.4)$ & $0.57(0.26,1.25)$ \\
\hline & Third quartile & $0.433-2.825$ & 61 & $28(45.9)$ & $1.64(0.79,3.40)$ \\
\hline & Fourth quartile & $2.826-21.372$ & 62 & $22(35.5)$ & $0.91(0.42,1.98)$ \\
\hline & Highest decile & $6.232-21.372$ & 25 & $10(40.0)$ & $1.08(0.33,3.57)$ \\
\hline
\end{tabular}

$\mathrm{mg} / \mathrm{m}^{3}[14,19]$, which was lower than in previous studies in the United States $\left(1.1 \pm 0.5 \mathrm{mg} / \mathrm{m}^{3}\right)[21]$, Australia $\left(1.51 \pm 1.08 \mathrm{mg} / \mathrm{m}^{3}\right)[22]$ and South Africa $(0.9-1.9 \mathrm{mg} /$ $\left.\mathrm{m}^{3}\right)[23]$.

As a reminder, the frequency of chronic symptoms in the current study were $25.3 \%$ for any cough, 5.6\% for chronic cough, $13.3 \%$ for any cough with sputum, 3.2\% for chronic cough with sputum, $34.5 \%$ for short of breath when hurrying on level ground, and $8.1 \%$ for wheeze. The National Study of Coal Workers' Pneumoconiosis in the United States showed that 35\% of the workers employed in coal mines before 1970 had chronic bronchitis (chronic cough and phlegm), 43\% had shortness of breath and $42 \%$ had wheezing [7]. Seixas et al. [10] studied 1185 workers who started mining from 1970 and later; the prevalence of respiratory symptoms was lower, by reporting that $28 \%$ had cough, $32 \%$ phlegm, $21 \%$ chronic bronchitis, 22\% breathlessness and 27\% wheezing. Another study [11] among coal miners in the United States reported the prevalence of chronic bronchitis to be $33 \%$, and studies of coal miners in the United Kingdom found that the prevalence of chronic bronchitis was 37\% [5] and 39\% [24]. A study of coal mine workers in China [8] showed that $77 \%$ had breathlessness walking at a nor- mal pace on level ground, $47 \%$ had chronic cough and $37 \%$ had chronic phlegm.

The studies in the United Kingdom and the United States showed that chronic respiratory symptoms were associated with both smoking and dust exposure levels $[5,11,24]$. When converting gm $\mathrm{hr} / \mathrm{m}^{3}$ to $\mathrm{mg}$ - $\mathrm{yrs} / \mathrm{m}^{3}$ by using a factor of 1.74[4], the cumulative dust exposurefor coal miners of $250 \mathrm{gm}-\mathrm{hr} / \mathrm{m}^{3}$ reported by Rae et al. [24] is equivalent to $144 \mathrm{mg}$-yrs $/ \mathrm{m}^{3}$ which is close to $136.3 \mathrm{mg}$ $\mathrm{yrs} / \mathrm{m}^{3}$ presently found for development workers. Further, the mean age of the development workers of 36 years falls half way between the age groups of 25-34 and 35-44 described by Rae et al. [24]. For never-smokers in these two age groups, Rae et al. [24] reported an observed prevalence of cough with sputum for most days for 3 months of $20 \%$ and $22.2 \%$. This is about 3 times greater than $7.7 \%$ reported by the development workers in the present study.

Kibelstis et al [11] showed that in each age group cigarette smoking coal face workers had significantly higher prevalence of respiratory symptoms than their non-smoking counterparts. In the study by Seixas and co-workers [10], never smokers had lower prevalence of respiratory symp- 
toms than ex smokers and current smokers. However, the prevalence of respiratory symptoms in our study is lower than reported by Seixas et al [10] also among never-smokers.

The current prevalence of chronic cough of $5.6 \%$ is comparable to that reported by Naidoo et al. in South Africa (5.3\%), who also reported relatively low prevalence of cough $(9.0 \%)$, chronic phlegm $(8.6 \%)$ and chronic bronchitis $(7.5 \%)[23,25]$.

The prevalence of acute respiratory symptoms has to be interpreted with caution, as they correlate significantly with chronic symptoms. This may imply either that people with chronic symptoms also experience more acute symptoms or that people with chronic symptoms report the problem as an acute symptom. The definition of acute symptoms might confuse workers with chronic symptoms, thus exaggerating the acute respiratory problems among the coal mine workers.

The strengths of the current study include the availability of quantitative exposure data and the large contrast in exposure between the groups. However, we could only investigate relative differences in symptom prevalence between the exposed groups since we did not include an external group not exposed to mixed coal dust. The results indicate an association between dust exposure and respiratory symptoms, since stratification by smoking habits did not alter the significant difference in the prevalence of cough as much as 4-6 times a day for 4 days or more in a week and shortness of breath walking with people of own age between the groups; but a cross-sectional study cannot confirm causal relationships.

Further, information bias might have affected the reporting of symptoms. Our study took place when Tanzania was implementing public sector reform: moving from public ownership of industry into private or mixed publicprivate ownership. The planning of this process had started in the present mine at the time of our study and some workers were presumably afraid of losing their jobs because they could not be absorbed into the private sector immediately. In this context, some workers in the mine might not have given correct information on respiratory symptoms by thinking that such information could be used as a screening criterion to prevent future employment. This might have contributed to the low symptom prevalence observed in this study, although all workers were assured confidentiality during participation.

The healthy worker effect might also be an issue since only the current workers in the mine were studied. Workers who had developed respiratory symptoms and airflow limitation might have left the mining industry, thus contributing to underestimating the effect of exposure.

The use of respirable coal mine dust samples might be misleading, since the development of some of the respiratory symptoms might be more closely related to larger dust particles. However, Seixas et al. [26] addressed this issue and concluded that a respirable dust concentration is a sensible proxy for measuring larger particles. The exclusive use of current exposure data in the construction of cumulative exposure is a limitation of the study. However, according to the management the coal production was fairly stable for the past two decades and no major changes in the production processes had been done, indicating that the current data is representative for also the past exposures. The exposure levels were also similar in the two periods of sampling in this study.

This study was conducted in a mine in Tanzania, and the results may be difficult to generalize to other countries, although the information might be valid for the mines elsewhere with similar characteristics. However, the information obtained will be useful in improving the working conditions in the mine.

\section{Conclusion}

This study, the first of its kind among miners in Tanzania, describes the relationship between coal mine dust and respiratory symptoms. The development workers had a greater risk of experiencing respiratory symptoms. This information is important for raising awareness among policy-makers and the workers and employers in the mine sector. It is also useful in setting priorities for prevention strategies.

\section{Competing interests}

The author(s) declare that they have no competing interests.

\section{Authors' contributions}

SHDM designed and conducted the study, performed statistical analysis, wrote the initial draft and revised the manuscripts after consultation with the other authors. MB, YM and BEM participated in designing the study and revising the manuscript. All authors have read and approved the final manuscript.

\section{Acknowledgements}

We thank the workers and management of the Kiwira Coal Mine. This work was supported by the Norwegian State Education Loan Fund (Lånekassen), the Norwegian Council of University Committee for Development Research and Education (NUFU), the Centre for International Health and the Section for Occupational Medicine, University of Bergen. 


\section{References}

I. Miller BG, Jacobsen M: Dust exposure, pneumoconiosis, and mortality of coalminers. $\mathrm{Br} /$ Ind Med 1985, 42:723-733.

2. Morgan WK, Lapp NL, Seaton D: Respiratory disability in coal miners. Jama 1980, 243:240|-2404.

3. Rae S: Pneumoconiosis and coal dust exposure. $\mathrm{Br}$ Med Bull I97I, 27:53-58.

4. Rogan JM, Attfield MD, Jacobsen M, Rae S, Walker DD, Walton WH Role of dust in the working environment in development of chronic bronchitis in British coal miners. Br J Ind Med 1973, 30:217-226.

5. Marine WM, Gurr D, Jacobsen M: Clinically important respiratory effects of dust exposure and smoking in British coal miners. Am Rev Respir Dis 1988, I37:106-II2.

6. Carta P, Aru G, Barbieri MT, Avataneo G, Casula D: Dust exposure, respiratory symptoms, and longitudinal decline of lung function in young coal miners. Occup Environ Med 1996, 53:3 I2-319.

7. Henneberger PK, Attfield MD: Respiratory symptoms and spirometry in experienced coal miners: effects of both distant and recent coal mine dust exposures. Am J Ind Med I997, 32:268-274.

8. Wang X, Yu IT, Wong TW, Yano E: Respiratory symptoms and pulmonary function in coal miners: looking into the effects of simple pneumoconiosis. Am J Ind Med 1999, 35: | 24- | 3 I.

9. Ashford JR, Morgan DC, Rae S, Sowden RR: Respiratory symptoms in British coal miners. Am Rev Respir Dis 1970, 1 02:370-381.

10. Seixas NS, Robins TG, Attfield MD, Moulton LH: Exposureresponse relationships for coal mine dust and obstructive lung disease following enactment of the Federal Coal Mine Health and Safety Act of 1969. Am J Ind Med 1992, 21:7I5-734.

II. Kibelstis JA, Morgan EJ, Reger R, Lapp NL, Seaton A, Morgan WK: Prevalence of bronchitis and airway obstruction in American bituminous coal miners. Am Rev Respir Dis 1973, 108:886-893.

12. Naidoo R, Seixas N, Robins T: Estimation of respirable dust exposure among coal miners in South Africa. J Occup Environ Hyg 2006, 3:293-300.

13. Crawford NP, Bodsworth PL, Hadden GG, Dodgson J: A study of apparent anomalies between dust levels and pneumoconiosis at British collieries. Ann Occup Hyg 1982, 26:725-744.

14. Mamuya SH, Bratveit M, Mwaiselage J, Mashalla YJ, Moen BE: High Exposure to Respirable Dust and Quartz in a Labour-intensive Coal Mine in Tanzania. Ann Occup Hyg 2006, 50: 197-204.

I5. Mwaiselage J, Bratveit M, Moen BE, Mashalla Y: Respiratory symptoms and chronic obstructive pulmonary disease among cement factory workers. Scand J Work Environ Health 2005, 31:316-323.

16. Wasserfallen JB, Gold K, Schulman KA, Baraniuk JN: Development and validation of a rhinoconjunctivitis and asthma symptom score for use as an outcome measure in clinical trials. J Allergy Clin Immunol 1997, 100:16-22.

17. British Medical Research Council (BMRC): Standardized questionnaire on respiratory symptoms. $B r$ Med J 1960, 2:

18. ACGIH: Threshold limit values and biological exposure indices for chemical substances and physical agents. Cincinati, $\mathrm{OH}, \mathrm{ACGIH} ; 2002$.

19. Mamuya SH, Bratveit M, Mwaiselage J, Moen BE: Variability of exposure and estimation of cumulative exposure in a manually operated coal mine. Ann Occup Hyg 2006, 50:737-745.

20. Stevens J: Applied multivariate statistics for the social sciences. Mahway, New Jersey, Lawrence Erlbaum; 1996:72.

21. Kuempel ED, Attfield MD, Vallyathan V, Lapp NL, Hale JM, Smith RJ, Castranova V: Pulmonary inflammation and crystalline silica in respirable coal mine dust: dose-response. J Biosci 2003, 28:6I-69.

22. Kizil GV, Donoghue AM: Coal dust exposures in the longwall mines of New South Wales, Australia: a respiratory risk assessment. Occup Med (Lond) 2002, 52:137-149.

23. Naidoo RN, Robins TG, Seixas N, Lalloo UG, Becklake M: Respirable coal dust exposure and respiratory symptoms in SouthAfrican coal miners: a comparison of current and ex-miners. J Occup Environ Med 2006, 48:581-590.

24. Rae S, D.D W, Attfield MD: Chronic bronchitis and dust exposure in British coalminers. In Inhaled particles II Edited by: Walton WH. s, ; 1970:883-896.

25. Naidoo RN, Robins T, Seixas NS: Respiratory diseases among South African coalminers. Health 607 SIMRAC Report.
Johanesburg, Safety in Mines Research Advisory Committee(SIMRAC); 2002

26. Seixas NS, Hewett P, Robins TG, Haney R: Variability of particle size-specific fractions of personal coal mine dust exposures. Am Ind Hyg Assoc J 1995, 56:243-250.

\section{Pre-publication history}

The pre-publication history for this paper can be accessed here:

http://www.biomedcentral.com/1471-2458/7/17/prepub
Publish with Biomed Central and every scientist can read your work free of charge

"BioMed Central will be the most significant development for disseminating the results of biomedical research in our lifetime. "

Sir Paul Nurse, Cancer Research UK

Your research papers will be:

- available free of charge to the entire biomedical community

- peer reviewed and published immediately upon acceptance

- cited in PubMed and archived on PubMed Central

- yours - you keep the copyright 